\title{
IMPLEMENTASI LITERASI DAN MOTIVASI MEMBACA SISWA DI SMKN 1 OMBEN SAMPANG
}

\author{
Ali Wafa \& Moh. Wardi \\ IAI Nazhatut Thullab Sampang \\ Email: awafa9851@gmail.com
}

\begin{abstract}
Abstrak:
Penelitian ini menggunakan pendekatan kualitatif. Metode pengumpulan datanya menggunakan observasi, wawancara mendalam dan dokumentasi. Dalam pemilihan sumber data menggunakan purposive sampling karena pertimbangan tertentu. Berdasarkan hasil penelitian, bahwa: Pertama, motivasi baca siswa SMKN 1 Omben masih tergolong rendah, yang disebabkan oleh banyak faktor, yaitu: faktor letak geografis (pedesaan); paradigma orang tua termasuk masyarakat pada umumnya; orang tua perantau (TKI/TKW); kurangnya kesadaran siswa; kurangnya hubungan atau kerjasama antara orang tua dengan sekolah; pengaruh perkembangan teknologi. Kedua, ada dua peran guru dalam meningkatkan motivasi baca siswa: peran sebagai motivator dan peran sebagai fasilitator, guru memberikan atau menyediakan berbagai fasilitas yang dapat memudahkan siswa dalam proses belajar. Ketiga, implementasi literasi sebagai kegiatan yang wajib untuk berkunjung ke perpustkaan sekolah selama 35 menit sesuai dengan jadwal yang sudah ditentukan oleh pihak pengelola perpustakaan. Tujuannya untuk menumbuhkan kesadaran siswa tentang pentingnya membaca dan untuk menambah wawasan ilmu pengetahuan.
\end{abstract}

Kata Kunci: Motivasi, membaca, Literasi

\begin{abstract}
:
This research uses a qualitative approach. The data collection method uses observation, in-depth interviews and documentation. In selecting data sources using purposive sampling because of certain considerations. Based on the results of the study, that: First, the motivation to read SMKN 1 Omben students is still relatively low, which is caused by many factors, namely: geographical location factors (rural); the paradigm of parents including society in general; immigrant parents (TKI/TKW); lack of student awareness; lack of relationship or cooperation between parents and school; the influence of technological development. Second, there are two roles of the teacher in increasing students' reading motivation: the role of a motivator and the role of a facilitator, the teacher providing or providing various facilities that can facilitate students in the learning process. Third, the implementation of literacy as a mandatory activity to visit the school library for 35 minutes in accordance with the schedule determined by the library manager. The aim is to foster student awareness of the importance of reading and to broaden scientific insights.
\end{abstract}

Keywords: Motivation, Read, Literacy 


\section{Pendahuluan}

Sekolah Menengah Kejuruan (SMKN) 1 Omben merupakan satu satunya sekolah kejuruan yang berstatus negeri di kecamatan Omben kabupaten Sampang. Sebagai satu-satunya sekolah kejuruan yang berstatus negeri, maka sekolah ini menjadi tumpuan siswa di kecamatan Omben, bahkan tidak hanya dari kecamatan Omben saja, melainkan juga dari kecamatan Camplong dan Krangpenang Sampang. Sekolah kejuruan ini letaknya sangat strategis yaitu, terletak di jalan raya Sogian yang menghubungkan jalan raya ke kota Sampang dan Karangpenang. Karena letaknya yang strategis ini sehingga sekolah ini menjadi salah satau tumpuan siswa dari beberapa kecamatan terdekat, khususnya kecamatan Omben.

Sebagaimana disampaikan oleh kepala sekolah, bahwa kesadaran dan motivasi baca siswa sekolah masih rendah, yang hal ini disebabkan oleh banyak faktor, di antaranya adalah faktor letak geografis (pedesaan), kurangnya kesadaran orang tua termasuk masyarakat umum akan pentingnya pendidikan, orang tua perantau baik di dalam maupun di luar negeri, kurangnya kesadaran siswa, kurangnya komunikasi antara orang tua dengan pihak sekolah, pengaruh perkembangan teknologi dan lain-lain. Semua faktor tersebut sangat berpengaruh pada motivasi belajar siswa. Lebih lanjut disampaikan kepala sekolah, bahwa dalam rangka mendorong motivasi baca atau belajar siswa, kami selaku pihak sekolah mengimplementasikan literasi yang pelaksaannya masih terbatas di perpustakaan sekolah dengan mengikuti ketentuan jadwal yang sudah dibuat oleh pihak pengelola perpustakaan. ${ }^{1}$

Sebagaimana juga disampaikan oleh waka kurikulum, dengan implementasi literasi tersebut diharapkan menjadi dapat mengatasi masalah di atas, sehingga mendorong daya baca atau belajar siswa. Selain itu, implementasi literasi ini sebagai bentuk pengembangan potensi dan menambah wawasan pengetahuan siswa dalam semua aspek, khususnya dalam ranah kognitif, afektif dan psikomotorik. Namun, dalam implementasinya masih disesuaikan dengan kondisi sekolah dan siswa, karena sekolah kami masih tergolong mudah berdiri tahun 2014. Karena demikian, tentu masih banyak kekurangan-kekurangan atau kelemahan dalam implementasi literasi tersebut. Baik dalam hal kelengkapan koleksi buku maupun dalam hal pelayanan yang diberikan oleh pihak perpustakaan. Kekurangan-kekurangan tersebut akan terus kami perbaiki demi kemajuan sekolah dan peningkatan kualitas lulusan.

Oleh karenanya, kegiatan implementasi literasi ini perlu dukungan dari semu warga sekolah, yakni semua tenaga kependidikan dilingkungan SMKN 1 Omben Sampang demi tercapai tujuan bersama. Sebab mereka juga mempunyai peran pinting terhadap keberhasilan belajar siswa di sekolah. ${ }^{2}$ Selanjutnya, juga disampaikan oleh kepala perpustakaan, kami dan para pengelola sekolah tetap akan berupaya memperbaiki kekurangan-kekurangan tersebut sebaik mungkin untuk memenuhi kebutuhan siswa, baik yang berkaitan dengan koleksi dan pelayanan tersebut. Apalagi kegiatan literasi sangat menunjang terhadap keberhasilan proses belajar siswa, sebab dapat mengembangkan potensi dan menambah wawasan

\footnotetext{
${ }^{1}$ Wawancara dengan bapak Budi Purwanto selaku kepala SMKN 1 Omben Sampang pada tanggal 28 Oktober 2019.

${ }^{2}$ Wawancara dengan bapak Ahmad Fauzi selaku waka kurikulum pada tanggal 10 Oktober 2019.
} 
pengetahuan mereka. Di sisi lain, tujuan implementasi literasi sekolah sebagai bentuk tuntutan kurikulum 2013, di mana setiap satuan pendidikan dituntut menerapkannya sebagai bekal kecakapan abad 21 pada diri siswa. Siswa dapat belajar di mana dan kapan saja sesuai gaya mereka. ${ }^{3}$

Dengan demikian, diharapkan dapat meningkatkan kualitas pendidikan atau kualitas lulusan sekolah, sehingga lulusan dari sekolah ini nantinya benar-benar menjadi harapan masyarakat khususnya dunia kerja. Lebih lanjut, hal ini sebagaimana yang terdapat dalam Undang-undang Sistem Pendidikan Nasional Bab II Pasal 2 disebutkan bahwa pendidikan nasional berdasarkan Pancasila dan Undang-Undang Dasar Negara Republik Indonesia Tahun 1945. Pasal 3 Pendidikan nasional berfungsi mengembangkan kemampuan dan membentuk watak serta peradaban bangsa yang bermartabat dalam rangka mencerdaskan kehidupan bangsa, bertujuan untuk berkembangnya potensi peserta didik agar menjadi manusia yang beriman dan bertakwa kepada Tuhan Yang Maha Esa, berakhlak mulia, sehat, berilmu, cakap, kreatif, mandiri, dan menjadi warga negara yang demokratis serta bertanggung jawab. ${ }^{4}$

Dalam rangka mengembangkan potensi siswa sebagaimana yang terdapat dalam tujuan pendidikan nasional di atas, tentu juga harus ditunjang oleh komponen lain, seperti sarana dan prasarana sekolah yang memadai sehingga proses belajar mengajar tidak berpusat kepada guru atau teacher centred. Komponen lain yang juga tidak kalah penting dalam meningkatkan motivasi belajar siswa adalah perpustkaan sekolah. Dengan adanya perpustakaan tersebut diharapkan siswa lebih madiri dan bahkan dituntut untuk lebih aktif mencari dan menemukan materi pelajarn. Oleh karena itu, pihak sekolah khususnya kepala sekolah merasa penting mengembangkan gerakan literasi sekolah.

Sejalan dengan masalah di atas, saat ini pemerintah khususnya Kemendikbud tengah menumbuhkan Gerakan Literasi Sekolah (GLS). Hal ini dilatarbelakangi oleh berbagai riset yang menunjukkan bahwa tingkat literasi di kalangan masyarakat khususnya siswa masih rendah. Hasil penelitian Programme for International Student Assessment (PISA) menyebut, budaya literasi masyarakat Indonesia pada 2012 terburuk kedua dari 65 negara yang diteliti di dunia. Indonesia menempati urutan ke 64 dari 65 negara tersebut. Sementara Vietnam justru menempati urutan ke-20 besar. Pada penelitian yang sama, PISA juga menempatkan posisi membaca siswa Indonesia di urutan ke 57 dari 65 negara yang diteliti. PISA menyebutkan, tak ada satu siswa pun di Indonesia yang meraih nilai literasi ditingkat kelima, hanya 0,4 persen siswa yang memiliki kemampuan literasi tingkat empat. Selebihnya di bawah tingkat tiga, bahkan di bawah tingkat satu.

Data statistik UNESCO 2012 yang menyebutkan indeks minat baca di Indonesia baru mencapai 0,001. Artinya, setiap 1.000 penduduk, hanya satu orang saja yang memiliki minat baca. Angka UNDP juga mengejutkan bahwa angka melek huruf orang dewasa di Indonesia hanya 65,5 persen saja. Sedangkan Malaysia sudah 86,4 persen. Sebuah survei yang dilakukan Central Connecticut State University di

\footnotetext{
${ }^{3}$ Wawancara dengan bapak Arief Mulyanto selaku kepala perpustakaan pada tanggal 10 Oktober 2019.

${ }^{4}$ https://kelembagaan.ristekdikti.go.id/wpcontent/uploads/2016/08/UU no 20 th 2003.pdf/diak ses pada tanggal 11 Oktober 2019.
} 
New Britain yang bekerja sama dengan sejumlah peneliti sosial menempatkan Indonesia di peringkat 60 dari 61 negara terkait minat baca. Survei dilakukan sejak 2003 hingga 2014. Indonesia hanya unggul dari Bostwana yang puas di posisi 61. Sedangkan Thailand berada satu tingkat di atas Indonesia, di posisi 59.5

Adapun kata motivasi diambil dari kata motif yang berarti daya dalam diri seseorang yang mendoronguntuk melakukan sesuatu, atau keadaan seseorang yang menyebabkan kesiapannya untuk memulai serangkaian tindakan. Sedangkan motivasi adalah suatu proses untuk menggiatkan motif-motif menjadi perbuatan atau tingkah laku untuk memenuhi kebutuhan dan mencapai tujuan, atau keadaan dan kesiapan dalam diri individu yang mendorong tingkah lakunya untuk berbuat sesuatu dalam mencapai tujuan tertentu. ${ }^{6}$

Pengertian dasar motivasi adalah keadaan internal organisme baik manusia maupun hewan yang mendorong untuk berbuat sesuatu. Dalam pengertian ini motivasi berarti pemasok daya (energizer) untuk bertingkah laku secara terarah. ${ }^{7}$ Banyak macam motivasi dan para ahli meneliti tentang bagaimana asal dan perkembangan sehingga menjadi suatu daya dalam mengarahkan pada tindakan individu. Bahkan, motivasi diakui sebagai hal yang sangat penting bagi keberhasilan pelajaran siswa di sekolah. ${ }^{8}$ Dengan demikian, motivasi baca siswa merupakan kegiatan atau aktivitas yang mendorong seorang siswa untuk membaca atau belajar. Dorongan tersebut dapat dipengaruhi faktor internal maupun eksternal siswa.

Motivasi dibedakan menjadi dua macam: (1) motivasi intrinsik dan (2) motivasi ekstrinsik. Pertama, motivasi intrinsik adalah hal dan keadaan yang berasal dari dalam diri siswa sendiri yang dapat mendorongnya melakukan tindakan belajar. Dalam prspektif psikologi kognitif, motivasi yang lebih signifikan bagi siswa adalah motivasi intrinsik karena lebih murni dan langgeng serta tidak bergantung pada dorongan atau pengaruh orang lain. ${ }^{9}$ Motivasi ini timbul tanpa ada paksaan dan dorongan dari orang lain, tetapi atas kemauan sendiri. Kedua, motivasi ekstrinsik adalah hal atau keadaan yang datang dari luar siswa yang juga mendorongnya untuk melakukan kegiatan belajar. Pujian, hadiah, pearturan, tata tertib sekolah, suri tauladan orang tua, guru, dan lain sebagainya merupakan bentuk contoh dari motivasi ekstrinsik yang dapat mendorong siswa untuk belajar. Motivasi ini juga timbul karena adanya ajakan, suruhan atau paksaan dari orang lain sehingga ia mau melakukan tindakan belajar. ${ }^{10}$

Faktor eksternal siswa terdiri atas dua macam, yakni: (1) faktor lingkungan sosial dan (2) faktor lingkungan nonsosial. Pertama, lingkungan sosial. Lingkungan ini dibedakan menjadi tiga: (a) lingkungan sosial sekolah; (b) lingkungan masyarakat atau tetangga; dan (c) lingkungan sosial keluarga atau orang tua. Kedua, lingkungan nonsosial, seperti gedung sekolah dan letaknya, rumah tempat tinggal

\footnotetext{
5https://www.kompasiana.com/idrisapandi/5c920da695760e26c9003b35/pentingnya-literasibaca-tulis-abad-ke-21?page=all/diakses pada tanggal 08 Nuvember 2019.

${ }^{6}$ Moh. Uzer Usman, Menjadi Guru Profesional, edisi kedua, (Bandung: PT Remaja Rosdakarya, 2004), 28-29.

7 Muhibbin Syah, Psikologi Belajar, (Jakarta: Rajawali Pers, 2012), 153.

${ }^{8}$ S. Nasution, Berbagai Pendekatan Dalam Proses Belajar dan Mengajar, (Jakarta: Bumi Aksara, 2013), 180.

${ }^{9}$ Syah, Psikologi Belajar, 153.

10Usman, Menjadi Guru Profesional, 29.
} 
keluarga siswa dan letaknya, alat-alat belajar, keadaan cuaca dan waktu belajar yang digunakan siswa. ${ }^{11}$ Semua faktor di atas juga mempengaruhi terhadap motivasi baca atau belajar siswa.

Ada beberapa cara dalam membangkitkan motivasi belajar siswa, baik internal maupun eksternal, antara lain: (1) Kompetisi (persaingan). Dalam hal ini, guru berusaha menciptakan persaingan di antara siswa untuk meningkatkan prestasi belajarnya; (2) Pace making (membuat tujuan sementara atau dekat). Pada awal kegiatan belajar-mengajar, guru hendaknya menyampaikan tujuan yang akan dicapai; (3) Tujuan yang jelas. Motif dorongan siswa untuk mencapai tujuan. Semakin jelas tujuan, makin besar nilai tujuan bagi siswa dan makin besar pula motivasi dalam melakukan suatu perbuatan; (4) Kesempurnaan untuk sukses. Seorang guru hendaknya banyak memberikan kesempatan kepada siswa untuk meraih kesuksesan dengan usaha sendiri, tentu saja dengan bimbingan guru; (5) Minat yang besar. Motif akan timbul jika siswa memiliki minat yang besar; dan (6) Mengadakan penilaian atau tes. Pada umumnya siswa mau belajar dengan tujuan memperoleh nilai yang baik. ${ }^{12}$

Di SMKN 1 Omben, motivasi baca siswa masih tergolong rendah yang disebabkan banyak faktor. Kemudian oleh pihak sekolah melakukan alternatif melalui implementasi literasi meskipun masih terbatas pada ruang dan tempat tertentu. Jadi, implementasi literasi ini merupakan kegiatan wajib berkunjung ke perputakaan sesuai jadwal yang telah ditentukan oleh pihak perpustakaan. Dari konteks di atas, peneliti sangat tertarik untuk mengkaji kegiatan ini lebih dalam, sebab kegiatan literasi yang diterapakn di SMKN 1 Omben ini termasuk hal yang baru-baru untuk jenjang sekolah kejuruan, kususnya di Kabupaten Sampang. Dalam hal peneliti akan memfokuskan pada masalah berikut: (1) analisis motivasi baca siswa di SMKN 1 Omben; (2) peran guru dalam meningkatkan motivasi baca siswa di SMKN 1 Omben; dan (3) implementasi literasi sebagai kecakapam abad 21 di SMKN 1 Omben.

\section{Metode Penelitian}

Penelitian ini menggunakan pendekatan kualitatif, karena penelitian jenis ini sangat cocok untuk mendiskripsikan temuan-temuan data yang diperoleh dari lapangan. Di samping itu, metode ini cocok digunakan untuk mendapatkan data yang mendalam tentang fenomena yang terjadi di lapangan, suatu data yang mengandung makna. Makna yang dimaksud adalah data yang sebenarnya, data yang pasti yang merupakan suatu nilai dibalik data yang tampak. ${ }^{13}$ Dalam hal ini adalah data yang berkaitan dengan judul penelitian.

Kemudian, dalam pengumpulan data, peneliti menggunakan teknik observasi partisipatif, wawancara mendalam dan dokumentasi. Observasi partisipatif yakni penilti terlibat dengan kegiatan sehari-hari pada objek yang sedang diamati. ${ }^{14}$ Teknik wawancara dilakukan dengan efektif, artinya dalam kurun waktu yang

\footnotetext{
11Syah, Psikologi Belajar, 154-155.

12Usman, Menjadi Guru Profesional, 29-30.

13 Sugiyono, Metode Penelitian Kuantitatif, Kualitatif Dan R\&D, cetakan ke-26, (Bandung: Alfa Beta, 2017), 9.

14 Sugiyono, Metode Penelitian Kuantitatif, Kualitatif Dan R\&D, 227.
} 
sesingkat-singkatnya dapat diperoleh data sebanyak-banyknya. ${ }^{15}$ Dalam hal ini peneliti mengumpulkan data yang berkaitan dengan judul penelitian.

Dalam pemilihan sumber data, peneliti menggunakan purposive sampling, yakni peneliti memilih informan yang dianggap lebih banyak mengetahui informasi dan masalahnya secara mendalam dan dapat dipercaya untuk menjadi sumber data yang mantab. ${ }^{16}$ Dalam kaitan dengan penelitan ini, maka peneliti memilih kepala sekolah, wakil kepala, guru dan siswa sebagai sumber data.

\section{Pembahasan dan Hasil Penelitian}

\section{Analisis Motivasi Baca Siswa di SMKN 1 Omben}

Salah satu tujuan implementasi literisi sekolah, sebagai bentuk respon dari tuntutan kurikulum 2013, di samping mengingat kesadaran dan motivasi baca siswa masih tergolong rendah. Rendahnya motivasi baca tersebut, disebabkan oleh banyak faktor, yaitu: (1) faktor letak geografis (pedesaan); (2) kurangnya kesadaran akan pentingnya pendidikan bagi orang tua termasuk masyarakat umum; (3) orang tua perantau; (4) kurangnya kesadaran siswa; (5) kurangnya hubungan atau kerjasama antara orang tua dengan sekolah; (6) pengaruh perkembangan teknologi dan lain-lain. Namun, di sisi lain, SMKN 1 Omben juga sering meraih juara, baik tingkat kecamatan Omben maupun tingkat kabupaten Sampang. Misalnya, pada bulan Agustus 2019 sekolah ini meraih juara II Gerak jalan yang dilaksanakan oleh Kecamatan Omben. Pada bulan yang sama, juga meraih juara II pancak silat yang dilaksanakan oleh Cabang Dinas Kabupaten Sampang tingkat SMK dan SMA se Kabupaten Sampang Madura.

Semua faktor di atas sanagt berpengaruh negatif terhadap keberhasilan proses pembelajaran siswa di sekolah. Misalnya, pertama, kurangnya kesadaran siswa pada pendidikan akan berpengaruh negatif, yakni siswa cenderung kurang semangat dalam mengikuti pembelajaran. Mereka hanya sekedar menghilangkan kewajiban saja sebagai usia sekolah. Kedua, keluarga perantau. Pada umumnya anak keluarga perantau kurang memiliki semangat belajar, karena kurangnya pantauan dari pihak orang tua. Bahkan yang paling parah adalah kurangnya komunikasi antara orang tua dengan sekolah. Yang lebih memprihatinkan lagi apabila orang tua pasrah penuh kepada sekolah atas terhadap pendidikan anak-anaknya. ${ }^{17}$

Keluarga dengan sekolah merupakan satu kesatuan yang tidak dapat dipisahkan dari pengelolaan sekolah. Keduanya sangat erat, artinya orang tua atau keluarga harus peduli dengan program sekolah sehingga tercapai sebagaimana yang diharapkan masyarakat. Dalam teori hubungan keluarga dengan sekolah menyatakan bahwa sekolah dan keluarga memiliki tanggung jawab yang sama dalam mendidik siswa. Pendapat yang extrim mengatakan bahwa setiap sekolah harus mengetahui keluarga tiap-tiap siswa. Sebaliknya, orang tua harus

\footnotetext{
15 Suharsimi Arikunto, Prosedur Penelitian Suatu Pendekatan Praktik, (Jakarta: Rineka Cipta, 2013), 271.

16 Masykuri Bakri, Metode Penelitian Kualitatif Tinjauan Teoritis dan Praktis, (Surabaya: Visipres Media, 2013), 124.

${ }^{17}$ Moh. Wardi. "Penerapan Nilai Pendidikan Agama Islam dalam Perubahan Sosial Remaja." TADRIS: Jurnal Pendidikan Islam 7.1 (2013): 31-44.
} 
mengadakan hubungan baik untuk mengetahui kemajuan-kemajuan anaknya di sekolah. ${ }^{18}$

Tidak kalah juga dengan peran pendidikan di dalam masyarakat, di mana masyarakat merupakan lapangan pendidikan yang ketiga. Para guru pada umumnya sepakat bahwa lapangan pendidikan yang ikut mempengaruhi perkembangan siswa adalah keluarga, pendidikan sekolah dan lingkungan masyarakat. Hubungan antara ketiga lembaga pendidikan ini akan memberi dampak positif bagi perkembangan siswa termasuk dalam pembentukan jiwa keagamaan mereka. ${ }^{19}$ Selanjutnya, dikatakan bahwa pendidikan adalah tanggung jawab bersama antara keluarga, masyarakat dan sekolah atau pemerintah. Sekolah hanyalah pembantu kelanjutan pendidikan dalam keluarga sebab pendidikan yang pertama dan utama diperoleh anak adalah dalam keluarga. Peralihan bentuk pendidikan jalur luar sekolah ke jalur pendidikan sekolah (formal) memerlukan kerja sama. ${ }^{20}$

Di samping itu, sebagaimana dijelaskan oleh waka kurikulum bahwa dalam rangka mendorong motivasi baca siswa, maka kami menerapkan literasi sekolah yang pelaksaannya masih terbatas di perpustakaan sekolah dengan mengikuti ketentuan jadwal yang sudah dibuat oleh pihak pengelola perpustakaan. Hal itu juga menjadi pukulan berat bagi sekolah dalam sehingga implentasi literasi dirasa sangat penting di samping sebagai bentuk respon dari tuntutan kurikulum 2013. Karenanya implementasi literasi ini meruapakan inovasi baru di sekolah kami, yang tentu sanat butuh dukungan dari para wali siswa dan masyarakat sekitar, bahkan masyarakat umum. Sebab pada hakikatnya kegiatan pendidkan ini tidak mungkin mampu dipikul oleh warga sekolah saja, melainkan dukungan dari semua elemen masyarakat demi tercapainya sebuah tujuan pendidikan yang berkualitas.

Sudah seharusnya dengan masuknya anak ke sekolah, maka terbentuklah hubungan antara keluarga atau orang tua siswa dan sekolah. Orang tua harus menyesuaikan waktu dengan keperluan anak agar jangan terlambat sampai ke sekolah. Selain itu, orang tua harus menyediakan pakaian yang baik, supaya anaknya tidak malu terhadap teman-temannya di sekolah. Antara rumah dan sekolah harus tercipta hubungan, karena kedua lingkungan itu terdapat objek dan tujuan yang sama, yakni mendidik anak-anak. ${ }^{21}$ Manfaat adanya hubungan baik antara keluarga dan sekolah: (1) orang tua dan para guru saling kenal mengenal; (2) orang tua mengenal lingkungan dan suasana tempat anaknya belajar; (3) minat orang tua terhadap pelajaran anaknya bertambah besar; (4) orang tua mendapat pemahaman terkait pendidikan, khususnya mengenai masalah-masalah yang menyangkut anaknya sendiri; (5) jika ada perselisihan antara rumah dan sekolah dapat diatasi dan diselesaikan dengan penuh pengertian; dan (6) semangat orang tua dapat dibangkitkan untuk menyumbangkan tenaganya dalam pembangunan dan kemajuan sekolah. ${ }^{22}$

\footnotetext{
${ }^{18}$ H. Abu Ahmadi, Sosiologi Pendidikan Cetakan Kedua, (Jakarta: PT Rineka Cipta, 2007), 111-112.

19 H. Jaluddin, Psikologi Agama: Memahami Perilaku Keagamaan dengan Mengaplikasikan Prinsipprinsip Psikologi, (Jakarta: PT Rajagrafindo Persada, 2011), 297-298.

20 Hasbullah, Dasar-dasar Ilmu Pendidikan Umum dan Agama Islam, (Jakarta: PT Rajagrafindo Persada, 2009), 90.

21 Zakiah Daradjat, Ilmu Pendidikan Islam Cetakan Ke-10, (Jakarta: Bumi Aksara, 2012), 78.

22 Ibid., 79.
} 


\section{Peran Guru Dalam Meningkatkan Motivasi Baca Siswa di SMKN 1 Omben} a. Sebagai fasilatator

Berkaitan dengan peran ini, seorang guru tidak hanya mempunyai peran sebagai transfer ilmu pengetahuan atau informasi kepada siswa. Apalagi sekarang ini tuntutan kurikulum 2013, seorang guru bukan lagi sebagai satu-satunya sumber belajar sebagaimana dalam pembelajaran konvensional. Dalam artian, seorang siswa harus lebih aktif mencari dan menemukan materi pelajaran terutama bagi siswa jenjang menengah. Dengan demikian, siswa tidak hanya sebagai objek yang hanya mendengar dan mencatat apa yang disampaikan oleh guru, akan tetapi dia aktif dalam proses pembelajaran.

Dalam kaitannya dengan peran guru sebagai fasilitator tersebut, guru terutama sekolah harus memberikan atau menyediakan berbagai fasilitas yang dapat memudahkan siswa dalam proses belajar. Di samping itu, dapat memberikan pilihan atau kebebasan kepada siswa dalam belajar sesuai dengan gaya dan kemampuannya. Karena setiap siswa memiliki kemampuan yang berbeda dalam menangkap materi pelajaran. Dengan demikian, siswa tidak jenuh karena dapat belajat sesuai gaya, dan bahkan dapat belajar di mana saja dan kapan saja. Dalam hal ini, salah satu pelayanan yang disediakan SMKN 1 Omben, dengan diterapkannya literasi baca yang masih terbatas di Perpustakaan. Salah satu tujuannya adalah mengembangkan potensi siswa yang sesuai dengan gaya belajar masing-masing.

Sebagai fasilitator, guru berperan dalam memberikan pelayanan untuk memudahkan siswa dalam kegiatan proses pembelajaran. Agar dapat melaksanakan peran tersebut, guru perlu memahami: Pertama, berbagai jenis media dan sumber belajar serta fungsi masing-masing media itu. Kedua, guru perlu mempunyai keterampilan dalam merancang suatu media. Ketiga, guru dituntut untuk mampu mengorganisasikan berbagai jenis media serta dapat memanfaatkan berbagai sumber belajar. Keempat, guru sebagai fasilitator, dituntut agar mempunyai kemampuan dalam berkomunikasi dan berinteraksi dengan siswa. ${ }^{23}$

\section{b. Sebagai motivator}

Dalam proses pembelajaran motivasi merupakan salah satu aspek yang sangat penting. Sering terjadi siswa yang kurang berprestasi bukan disebabkan oleh kemampuannya yang kurang, tetapi dikarenakan tidak adanya motivasi untuk belajar sehingga ia tidak berusaha untuk mengerahkan segala kemampuannya. Motivasi erat kaitannya dengan kebutuhan, sebab memang motivasi muncul karena kebutuhan. ${ }^{24}$ Dengan demikian, motivasi ini sangat penting diberikan guru secara terus-menerus kepada siswa baik saat ataupun sesudah proses pembelajaran. Sebab tanpa didasari oleh motivasi yang kuat, maka siswa akan sulit untuk mempunyai semangat belajar yang tinggi. Bahkan pada hakikatnya pemberian motivasi ini tidak hanya menjadi tugas guru saja, melainkan juga orang tua sebagai pendidik utama dalam keluarga.

${ }^{23}$ H. Wina Sanjaya, Strategi Pembelajaran Berorientasi Standar Proses Pendidikan cetakan Ke-8, (Jakarta: Kencana, 2011), 23.

24 Ibid., 28. 
Dalam kaitannya peran guru di atas, terdapat beberapa faktor yang mempengaruhi keberhasilan proses pembelajaran siswa, yaitu: Pertama, faktor guru. Dalam hal ini guru merupakan komponen yang sangat menentukan dalam implementasi suatu strategi atau metode pembelajaran. Keberhasilan implementasi strategi tersebut tergantung pada kepiawaian guru dalam menggunakan metode, teknik dan taktik pembelajaran. Kedua, faktor siswa. Aspek latar belakang yang meliputi jenis kelamin siswa, tempat kelahiran, tempat tinggal, tingkat sosial ekonomi siswa, dari keluarga yang bagaimana siswa berasal dalan lain-lain. Aspek tersebut juga ikut andil dalam mempengaruhi pembelajaran siswa.

Ketiga, faktor sarana dan prasarana. Sarana yang dimaksud adalah segala sesuatu yang mendukung secara langsung terhadap kelancaran proses pembelajaran di sekolah. Misalnya, media pembelajaran, alat-alat pemeblajaran, perlengkapan sekolah, perpustakaan sekolah dan lain-lain. Prasarana adalah segala sesuatu yang secara tidak langsung dapat mendukung keberhasilan proses pembelajaran. Misalnya, jalan menuju sekolah, penerangan sekolah, kamar kecil, dan lain sebagainya. ${ }^{25}$

\section{Implementasi Literasi di SMKN 1 Omben}

Dalam implementai literasi ini di SMKN 1 Omben masih dilakukan secara sederhana dan fokus pada perpustakaan sekolah. Smua siswa diwajibkan berkunjung ke dalam perpustakan dengan tujuan membaca buku. Jam kunjungan tersebut sesuai jadwal yang sudah ditentukan oleh pihak perpustakaan yang sudah disesuaikan dengan jadwal pelajaran sehingga tidak alasan tidak masuk kelas karena jam kunjung ke perpustakaan. Kegitan membaca tersebut hanya berlangsung 35 menit. Kegiatan ini diharapkan menjadi solusi pada motivasi baca siswa yang selama ini daya baca mereka masih tergolong rendah, meskipun tidak seluruhnya demikian.

Di samping itu, dalam implementasi literasi ini, tentu tidak akan berjalan mulus, akan tetapi sudah pasti ada kendala yang dihadapi atau kekurangankekurangan, baik yang berkaitan dengan fasilitas atau koleksi perpustakaan; dari sisi siswa; guru atau tenaga kependidikan; tata kelola perpustakaan; maupun pelayanannya. Pertama, dari sisi fasilitas perpustakaan. Di mana ketersediaan koleksi buku masih kurang memadai, sehingga siswa sangat terbatas dalam membaca buku. Di samping itu, belum ada semacam surat kabar, koran dan majalah. Hal ini mangakibatkan siswa masih terfokus kepada buku saja. Surat kabar, koran dan majalah ini sangat penting bagi pengembangan wawasan siswa sebab, di langsung mengetahui semua fenomena yang terjadi di dunia.

Kekurangan-kekurangan di atas ditanggapi serius oleh kepala perpustakaan, kami dan para pengelola sekolah tetap akan berupaya memperbaiki kekurangankekurangan tersebut sebaik mungkin untuk memenuhi kebutuhan siswa, baik yang berkaitan dengan koleksi dan pelayanan tersebut. Apalagi kegiatan literasi sangat menunjang terhadap keberhasilan proses belajar siswa, sebab dapat mengembangkan potensi dan menambah wawasan pengetahuan mereka. Di sisi lain, tujuan implementasi literasi sekolah sebagai bentuk tuntutan kurikulum 2013,

25 Ibid., 52-55. 
di mana setiap satuan pendidikan dituntut menerapkannya sebagai bekal kecakapan abad 21 pada diri siswa. Siswa dapat belajar di mana dan kapan saja sesuai gaya mereka. ${ }^{26}$

Hal yang sama juga disampaikan oleh waka sarana dan prasarana, kekurangan-kekurangan tersebut akan segera ditangani dengan serius oleh kami selaku pihak yang berwenang di sekolah, sehingga memudahkam siswadalam membaca dan bahkan benar-benar menambah wawasan pengetahuan dan pemikiran siswa. Kedua, dari sisi siswa. Tidak semua siswa mengikuti kegiatan ini meskipun sudah dijdwal dan bahkan bagi siswa yang tidak berkunjung diberi sanksai oleh petugas perpustakaan. Namun, hal tersebut tidak menjadikan efek jera bagi sebagian siswa. Ketiga, dari sisi guru atau tenaga kependidikan. Begitu juga dengan tenaga kependidika, yakni tidak semua dari mereka yang mendukung terhadap keiatan ini. Sebagian guru, beranggapan bahwa hal itu tugas petugas perpustakaan. ${ }^{27}$

Implementasi literasi di SMKN 1 Omben ini selaras dengan wahyu pertama kali yang turun kepada Nabi Muhammad Saw menjelang diangkat menjadi rasalullah bagi seluruh alam semesta. Wahyu tersebut berisi tentang perintah membaca kepada Nabi Muhammad Saw hingga beberapa kali diperintah untuk membaca oleh Malaikat Jibril. Di sisi lain, wahyu tersebut memerintahkan agar kita selalu membaca sepanjang hayat, karena dengan membaca dapat menambah wawasan ilmu pengetahuan dan mengembangkan potensi yang dimilikinya.Sebagaimana yang teradapat dalam Q.S. Al-Alaq/96: 1-5, yaitu:

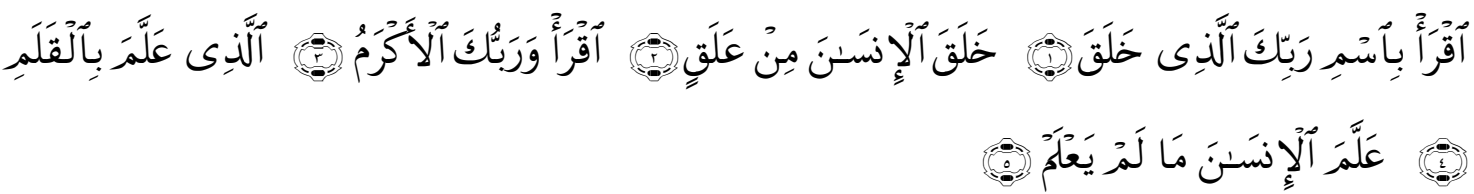

Artinya. Bacalah denagan (menyebut) nama Tuhan-Mu yang telah menciptakan. Dia telah menciptakan manusia dari segumpal darah. Bacalah, dan Tuhanmulah yang Maha Mulia. Dia yang mengajarkan manusia apa yang tidak diketahuinya (Q.S. AlAlaq/96: 1-5).28

Literasi berasal dari kata literacy yang artinya melek huruf, kemampuan bacatulis, kemelekwancanaan atau kecakapan dalam membaca dan menulis. Pengertian literasi berdasarkan konteks penggunaanya dinyatakan Baynham (1995) bahwa literasi merupakan integrasi keterampilan menyimak, berbicara, menulis, membaca, dan berpikir kritis. James Gee (1990) mengartikan literasi dari sudut pandang ideologis kewacanaan yang menyatakan bahwa literasi adalah penguasaan secara fasih suatu wacana sekunder.

Dari pandangan ilmu sosial, Robinson menyatakan bahwa literasi adalah kemampuan membaca dan menulis secara baik untuk berkompetisi ekonomis secara lengkap. Lebih lanjut dijelaskannya bahwa literasi merupakan kemampuan

\footnotetext{
26 Wawancara dengan bapak Arief Mulyanto selaku kepala perpustakaan pada tanggal 10 Oktober 2019.

27 Wawancara dengan bapak Moh. Romadhan selaku waka sarana dan prasarana, pada tanggal 20 Oktober 2019.

28 Depatemen Agama Republik Indonesia, Al-Quran dan Terjemahnya, (Kudus: Menara Kudus, 2006), 597.
} 
membaca dan menulis yang berhubungan dengan keberhasilan seseorang dalam lingkungan masyarakat akademis, sehingga literasi merupakan piranti yang dimiliki untuk dapat meraup kesuksesan dalam lingkungan sosial. National Assesment ofEducational Progress mengartikan literasi sebagai kemampuan performansi membaca dan menulis yang diperlukan sepanjang hayat (Winterowd). Seorang ahli hukum memandang bahwa literasi merupakan kompetensi dalam memahami wacana, baiksebagai pembaca maupun sebagai penulis sehingga menampakan pribadi sebagai profesional berpendidikan yang tidak hanya menerapkan untuk selama kegiatan belajar melainkan menerapkannya secara baik untuk selamanya. $^{29}$

Apalagi abad ke-21 ini disebut sbagai abad pengetahuan, abad ekonomi berbasis pengetahuan, abad teknologi informasi, globalisasi, revolusi industri 4.0, dan sebagainya. Pada abad ini, terjadi perubahan yang sangat cepat dan sulit diantisipasisecara sistematis,terstruktur, dan terukur. Salah satu contoh dari perubahan yang sangat cepat ini adalah dalam bidang teknologi informasi, khususnya media sosial. Belakangan media sosial ini telah dimanfaatkan oleh orangorang yang tidak bertanggung jawab untuk menyebarkan ujaran kebencian dan berita bohong (hoax). Berpikir kritis adalah salah satu upaya untukmenangkal informasi bohong yang tersebardi media sosial.

Sehingga keiatan literasi ini sangat penting bagi siswa dalam memilih, mengritisi, mengevaluasi, mensintesis, dan menggunakan informasi. Pada abad ini banyak sekali informasi yang beredar, dan bahkan tidaks edikit informasi tersebut merupakan informasi bohong. Jika kita tidak memiliki literasi informasi yang baik, maka kita akan"termakan"ole hisu- isu yang menyesatkan yang dapat membahayakan diri kita. Di sisi lain, berkaitan dengan literasi teknologi, siswa harus mampu menggunakan teknologi untuk berkomunikasi di era digital sekarang. ${ }^{30}$ Jika kita tutup mata terhadap perkembangan teknologi tersebut, maka kita akan ketinggalan dalam segala aspeknya.

Oleh kerenanya, pada abad ke-21 ini, kemampuan berliterasi sangat diperlukan oleh pemangku kepentingan didunia pendidikan, utamanya siswa. Kemampuan berliterasi siswa berkaitan erat dengan tuntutan keterampilan membaca yang berujung pada kemampuan memahami informasi secara analitis, kritis, dan reflektif. Akan tetapi, fakta pembelajaran di sekolah saat ini belum mampu mewujudkannya dengan baik. Tuntutan keterampilan abad 21 yang harus dikuasai dan pembelajaran di sekolah yang belum mampu menumbuhkan keterampilan atau kompetensi yang dibutuhkan menjadi dasar utama literasi harus dikembangkan. ${ }^{31}$

Sejak tahun 2016 Kementerian Pendidikan dan Kebudayaan menggiatkan Gerakan Literasi Nasional (GLN) sebagai bagian dari implementasi dari Peraturan

\footnotetext{
29 Suherli Kusuma, Pengembangan Literasi dalam Kurikulum Pendidikan Dasar dan Menengah, Diglosia: Jurnal Pendidikan, Kebahasaan, dan Kesusastraan Indonesia Vol. 1, No. 1 Februari 2017, 142-143.

30 I Wayan Redhana, Mengembangkan Keterampilan Abad Ke-21 Pada Pembelajaran Kimia, Jurnal Inovasi Pendidikan Kimia Vol. 13 No 1 2019, 2240

${ }^{31}$ Agus Widayoko, Supriyono Koes H \& Muhardjito, Analisis Program Implementasi Gerakan Literasi Sekolah (GLS) Dengan Pendekatan Goal-Based Evaluation, Jurnal Tatsqif: Jurnal Pemikiran dan Penelitian Pendidikan Volume16, No.1, Juni 2018, 79.
} 
Menteri Pendidikan dan Kebudayaan Nomor 23 Tahun 2015 tentang Penumbuhan Budi Pekerti. Gerakan Literasi Nasional merupakan upaya untuk memperkuat sinergi antarunit utama pelaku gerakan literasi dengan menghimpun semua potensi dan memperluas keterlibatan publik dalam menumbuhkembangkan dan membudayakan literasi di Indonesia," demikian Mendikbud. ${ }^{32}$

Selain itu, Kementerian Pendidikan dan Kebudayaan menerapkan Kurikulum 2013 Revisi 2017. Kurikulum ini diharapkan sudah menjawab kritik dan masalah ketika Kurikulum 2013 (Kurtilas) diberlakukan. Yang pasti, Kurikulum 2013 dan juga Revisi 2017 tetap menegaskan mengenai pentingnya Ketrampilan Abad 21. Ketrampilan Abad 21 yang dianggap bisa memperkuat modal social (social capital) dan modal intelektual (intellectual capital) ini, biasa disingkat dengan 4C: communication, collaboration, critical thinking and problem solving, dan creativity and innovation. Secara operasional, 4C ini dijabarkan dalam empat kategori langkah, yakni: Pertama, cara berpikir, termasuk berkreasi, berinovasi, bersikap kritis, memecahkan masalah, membuat keputusan, dan belajar pro-aktif. Kedua, cara bekerja, termasuk berkomunikasi, berkolaborasi, bekerja dalam tim. Ketiga, cara hidup sebagai warga global sekaligus local; dan keempat, alat untuk mengembangkan ketrampilan abad 21, yakni teknologi informasi, jaringan digital, dan literasi. ${ }^{33}$

Salah satu di antara enam literasi dasar yang perlu kita kuasai adalah literasi baca-tulis. Membaca dan menulis merupakan literasi yang dikenal paling awal dalam sejarah peradaban manusia. Keduanya tergolong literasi fungsional dan berguna besar dalam kehidupan sehari-hari. Dengan memiliki kemampuan bacatulis, seseorang dapat menjalani hidupnya dengan kualitas yang lebih baik. Misalnya, ketika menerima resep obat, dibutuhkan kemampuan untuk memahami petunjuk pemakaian yang diberikan oleh dokter. Jika salah, tentu akibatnya bisa fatal.

Dalam pelaksanaan kurikulum 2013, kegiatan literasi sebagai salah satu kegiatan yang wajib dilaksanakan guna menumbuhkan kesadaran siswa akan pentingnya membaca untuk menambah ilmu pengetahuan. Untuk dapat melaksanakan kegiatan literasi di sekolah, perlu adanya program literasi yang berisi tahapan-tahapan mulai tahap persiapan sampai pelaksanaan literasi. Persiapan pelaksanaan kegiatan literasi Kurikulum 2013 dimulai dengan rapat koordinasi oleh Kepala Sekolah. Kepala Sekolah membentuk tim Gerakan Literasi Sekolah (GLS) yang terdiri dari kepala perpustakaan, wali kelas, dan guru yang ditunjuk. Semua tim GLS mensosialisasikan kegiatan literasi kepada siswa. Persiapan sarana dan prasarana untuk GLS yaitu dengan melengkapi buku-buku bacaan umum dan literatur pelajaran sekolah.

Pelaksanaan literasi di sekolah dapat dilakukan melalui pembelajaran mapel tertentu. Siswa diberi tugas untuk membaca buku pengetahuan apa saja asalkan bukan yang terlarang. Tugas membaca buku bisa dilaksanakan di rumah atau di sekolah. Selanjutnya siswa diberi tugas merangkum apa yang sudah dibaca.

\footnotetext{
${ }^{32}$ https://minanews.net/budaya-literasi-syarat-kecakapan-hidup-di-abad-21/diakses pada tanggal 08 Nupember 2019

${ }^{33}$ https://pgsd.binus.ac.id/2017/08/08/kurikulum-baru-ketrampilan-abad-21-danimplementasinya/diakses pada tanggal 08 Nupember 2019.
} 
Rangkuman ditulis di kertas folio minimal 5 paragraf atau seribu kata. Siswa wajib mengumpulkan rangkuman hasil literasi setiap pembelajaran akan dimulai. Guru mencatat dan mengarsipkan rangkuman hasil literasi siswa untuk penunjang penilaian. ${ }^{34}$

Pengembangan literasi membaca buku, selain buku teks pelajaran ini dalam rangka memberikan fondasi literasi kepada mereka, agar dapat membekali mereka dengan literasi yang dibutuhkan dalam kehidupannya. Memang bukan target pencapaian jumlah buku yang harus dibaca, melainkan membiasakan mereka membaca dan membudayakan mereka untuk berpikir kritis berdasarkan wawasan yang dapat dikembangkan melalui kegiatan membaca. Para siswa harus memiliki kemampuan literasi lingkungan, literasi spasial, literasi matematikal, literasi teknologi, literasi budaya, literasi sosial, dan aspek-aspek lain yang bersentuhan dengan kehidupan siswa di masa yang akan datang. Pengembangan kemampuan literasi ini telah terlambat dikembangkan dilembaga pendidikan, namun demikian kita harus dapat memulainya sejak sekarang agar SDM bangsa Indonesia yang diharapkan dapat tercapai. ${ }^{35}$

\section{Penutup}

Tujuan implementasi literisi, bentuk tuntutan kurikulum 2013, di samping mengingat kesadaran dan motivasi baca siswa masih tergolong rendah. Rendahnya motivasi baca tersebut, disebabkan oleh banyak faktor, yaitu: faktor letak geografis (tergolong pedesaan); paradigma orang tua termasuk masyarakat pada umumnya; orang tua perantau; kurangnya kesadaran siswa; kurangnya hubungan atau kerjasama antara orang tua dengan sekolah; pengaruh perkembangan teknologi dan lain-lain. Di sisi lain, SMKN 1 Omben juga sering meraih juara, seperti gerak jalan baik tingkat kecamatan Omben maupun tingkat kabupaten Sampang. Demikian juga dengan pancak silat yang dilaksanakan oleh Cabang Dinas Kabupaten Sampang pernah juara II tingkat SMK dan SMA.

Setidaknya ada dua peran guru: pertama, sebagai fasilitator. Peran guru sebagai fasilitator, guru harus memberikan atau menyediakan berbagai fasilitas yang dapat memudahkan siswa dalam proses belajar. Kedua, sebagai motivator. Dalam proses pembelajaran motivasi merupakan salah satu aspek yang sangat penting. Sering terjadi siswa yang kurang berprestasi bukan disebabkan oleh kemampuannya yang kurang, tetapi dikarenakan tidak adanya motivasi untuk belajar sehingga ia tidak berusaha untuk mengerahkan segala kemampuannya. Motivasi erat kaitannya dengan kebutuhan, sebab memang motivasi muncul karena kebutuhan.

Implementasi literasi sebagai kecakapan abad 21 merupakan kegiatan yang wajib dilaksanakan sekolah yang mewajibkan kepada setiap siswa untuk berkunjung ke perpustakaan selama 35 menit sesuai dengan jadwal yang sudah ditentukan. Guna menumbuhkan kesadaran siswa akan pentingnya membaca dan untuk menambah wawasan ilmu pengetahuan siswa. Meskipun dalam

\footnotetext{
${ }^{34}$ https://radarkudus.jawapos.com/read/2019/10/15/160903/enam-literasi-dasar-danimplementasinya-dalam-gls/diakses pada tanggal 08 Nupember 2019

${ }^{35}$ Suherli Kusuma, Pengembangan Literasi dalam Kurikulum Pendidikan Dasar dan Menengah, Diglosia: Jurnal Pendidikan, Kebahasaan, dan Kesusastraan Indonesia Vol. 1, No. 1 Februari 2017, 148.
} 
implementasinya masih banyak kekurangan-kekurangan, akan tetapi pihak sekolah tetap berusaha akan memperbaikinya.

\section{Daftar Pustaka}

Agus Widayoko, Supriyono Koes H \& Muhardjito, Analisis Program Implementasi Gerakan Literasi Sekolah (GLS) Dengan Pendekatan Goal-Based Evaluation, Jurnal Tatsqif: Jurnal Pemikiran dan Penelitian Pendidikan, Vol. 16, No. 1 Juni, 2018

Ahmadi, H. Abu. Sosiologi Pendidikan Cetakan Kedua, (Jakarta: PT Rineka Cipta, 2007)

Arikunto, Suharsimi. Prosedur Penelitian Suatu Pendekatan Praktik, (Jakarta: Rineka Cipta, 2013)

Bakri, Masykuri. Metode Penelitian Kualitatif Tinjauan Teoritis dan Praktis, (Surabaya: Visipres Media, 2013)

Daradjat, Zakiah. Ilmu Pendidikan Islam Cetakan Ke-10, (Jakarta: Bumi Aksara, 2012)

H. Jaluddin, Psikologi Agama: Memahami Perilaku Keagamaan dengan Mengaplikasikan Prinsip-prinsip Psikologi, (Jakarta: PT Rajagrafindo Persada, 2011)

Hasbullah, Dasar-dasar Ilmu Pendidikan Umum dan Agama Islam, (Jakarta: PT Rajagrafindo Persada, 2009)

https://kelembagaan.ristekdikti.go.id/wpcontent/uploads/2016/08/UU no 20 th 2003.pdf/diakses pada tanggal 11 Oktober 2019.

https://minanews.net/budaya-literasi-syarat-kecakapan-hidup-di-abad-

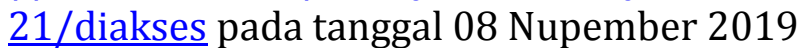

https://radarkudus.jawapos.com/read/2019/10/15/160903/enam-literasidasar-dan-implementasinya-dalam-gls/diakses pada tanggal 08 Nupember 2019

I Wayan Redhana, Mengembangkan Keterampilan Abad Ke-21 Pada Pembelajaran Kimia, Jurnal Inovasi Pendidikan Kimia Vol. 13 No 12019

Nasution, S. Berbagai Pendekatan Dalam Proses Belajar Dan Mengajar, (Jakarta: Bumi Aksara, 2013)

Sanjaya, H. Wina. Strategi Pembelajaran Berorientasi Standar Proses Pendidikan cetakan Ke-8, (Jakarta: Kencana, 2011)

Sugiyono, Metode Penelitian Kuantitatif, Kualitatif Dan R\&D, cetakan ke-26, (Bandung: Alfa Beta, 2017)

Suherli Kusuma, Pengembangan Literasi dalam Kurikulum Pendidikan Dasar dan Menengah, Diglosia: Jurnal Pendidikan, Kebahasaan, dan Kesusastraan Indonesia Vol. 1, No. 1 Februari 2017

Syah, Muhibbin. Psikologi Belajar, (Jakarta: Rajawali Pers, 2012)

Uzer Usman, Moh. Menjadi Guru Profesional, edisi kedua, (Bandung: PT Remaja Rosdakarya, 2004)

Wardi, Moh. "Penerapan Nilai Pendidikan Agama Islam dalam Perubahan Sosial Remaja." TADRIS: Jurnal Pendidikan Islam 7.1 (2013): 31-44. 